Chimia 46(1992) 335-337

(C) Neue Schweizerische Chemische Gesellschaft ISSN 0009-4293

\title{
The Fragmentation of
}

2,3-Dihydroisothiazol-3-one 1,1-Dioxide Derivatives: A Novel Cheletropic Process

\section{Kaspar F. Burri*}

Abstract. Adducts obtained by 1,3-dipolar cycloadditions to 2,3-dihydroisothiazol-3one 1,1-dioxides are inclined to undergo a cheletropic process, by which the newly formed heterocyclic part undergoes aromatization, while $\mathrm{SO}_{2}$ is extruded and an isocyanate is generated. The isocyanates are stable under the conditions of their formation, and are subject to standard isocyanate reactions. The process might be employed to synthesize isocyanates and derivatives of urethanes, ureas etc., whenever the use of mild and neutral reaction conditions is dictated by the sensitivity of the intermediates and products involved.

\section{Previous Studies}

The antiinflammatory agent tenoxicam 2b (Tilcoti $^{(\mathbb{B})}$ ), invented [1] and developed [2] at our research laboratories in the late 70 's and the early 80's, has been the target of considerable supportive and peripheral synthetic work [3][4]. In the course of these studies, access to structural types $2 \mathrm{a}$ and $\mathbf{2 b}$ (Scheme 1) and other related oxicam analogs was investigated. Specifically, various 1,3-dipolar cycloaddition reactions were carried out, inter alia establishing building blocks of the type 1 as useful dipolarophiles in several cases (for the synthesis of 1, see [3][5]). Especially with less reactive 1,3-dipoles, however, this procedure failed to yield the desired products; e.g., copious amounts of the triazole 5 (see [6] for an alternative preparation) were obtained, when the dipolarophile 1d was brought to reaction with the azide 3 (see [7] for the preparation and use of 3 ).

\section{A Novel, Concerted Process}

To explain the formation of 5 , we speculated that the reaction of 1 with the relatively inert 3 had initially taken its due course, forming the adduct 4 , but that the conditions required for the formation of 4 had sufficed for the initiation of a novel, concerted, cheletropic extrusion reaction, yielding three fragments: the triazole $\mathbf{5}$, benzyl isocyanate, and sulfur dioxide. An attempt was, therefore, made to gather evidence for this hypothesis, using the adduct 7a [3] (Scheme 2) because of its relative availability and stability.

Firstly, a base-induced mechanism had to be excluded, since the simultaneous formation of 5 and 6 might be considered to originate in a base-catalyzed $\mathrm{SO}_{2}$ elimination, followed by some sort of solvolysis and decarboxylation. In fact, when a solution of $7 \mathbf{a}$ in $\mathrm{CH}_{2} \mathrm{Cl}_{2}$ was treated with $\mathrm{Et}_{3} \mathrm{~N}$, elimination of $\mathrm{SO}_{2}$ proceeded at ambient temperature, yielding the carboxamide $\mathbf{8}$ as the sole product; no trace of a decarboxylated component was found. The structure of 8 was further confirmed by an acid-induced hydrolysis to the known [8] carboxylate 9 . It was tentatively concluded, that whatever trace of $\mathbf{6}$ had been formed in the azide reaction, this would most probably be the result of a similar base-induced elimination, presumably due to the presence of a trace of a basic impurity in the azide 3.

The adduct $7 \mathbf{a}$ was then subjected to the conditions used in the attempted azide addition, i.e. refluxing toluene. The known [9] 1,3-diphenylpyrazole 11 (Scheme 3) was indeed formed as the only detectable product. This finding considerably supported our notion concerning the origin of

*Correspondence: Dr. K.F. Burri

Pharma Division

Preclinical Research

F. Hoffmam-La Roche Ltd.

CH-4002 Basel

Scheme I

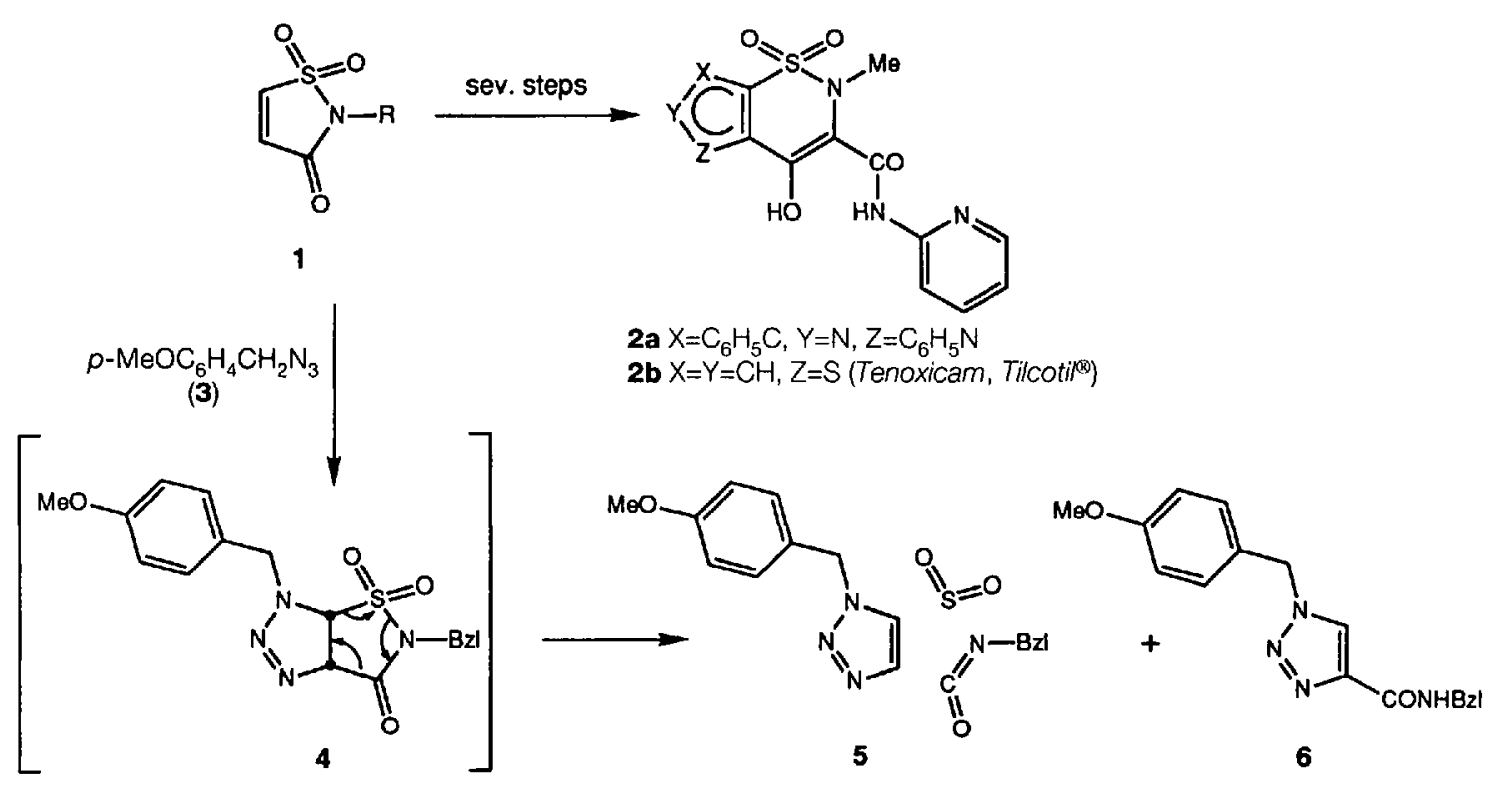


5 ; still, to propose the unfolding of a concerted fragmentation, we needed to prove the intermediate occurrence of an isocyanate species such as $10 \mathrm{~b}$ or $10 \mathrm{~d}$ of Scheme 3.

The problem was addressed using two further substrates, namely $\mathbf{7 b}$ and $\mathbf{7 d}$, both readily available by alkylation of $\mathbf{1 a}$ (see Exper. Part), followed by a reaction with diphenyl nitrile imine. The following experiments were carried out: solutions of the adducts $7 \mathbf{b}$ or $\mathbf{7 d}$, were maintained at reflux temperature in toluene for $1-5 \mathrm{~h}$ in the presence of $1-3$ equiv. of either $\mathrm{MeOH}$ or $\mathrm{PhCH}_{2} \mathrm{OH}$. The pyrazole 11 was generated quantitatively, along with the postulated methyl (12) or benzyl (13) carbamates, both isolated in $70-74 \%$ yield after chromatography. The isocyanates proved to be stable under the conditions of their formation; thus, when $\mathbf{7 d}$ was kept at reflux temperature for $1 \mathrm{~h}$ in the absence of proton donors, and the solution was then allowed to cool to ambient temperature, it contained the isocyanate 10d and the pyrazole 11 as the only components: the addi- tion of 1 equiv. of $\mathrm{PhCH}_{2} \mathrm{NH}_{2}$ initiated the instantaneous precipitation of the derived 1,3-dibenzylurea 14, which was isolated in $83 \%$ yield. These combined findings appear to secure the intermediacy of isocyanates and herewith the likelihood of a concerted mechanism, as is depicted in Schemes 1 and 3.

It may be argued, that the force driving the fragmentation is mainly the aromatization energy inadvertently gained during the reaction. Indeed, 15 (itself readily obtained by reducing 1c, see Exper. Part) turns out to be thermally stable, by no means undergoing a fragmentation process as outlined in Scheme 4.

\section{Applications}

Alkyl halides can be easily converted into the respective tetrahydroisothiazolone 1,1-dioxide derivatives by simply alkylating the Na salt of $\mathbf{1 a}$, as is standard procedure with e.g. the Na salt of saccharin or the $\mathrm{K}$ salt of phthalimide. With

\section{Scheme 2}<smiles>CCOCN1C(=O)C2CN(c3ccccc3)N=C(c3ccccc3)[C@H]2S(=O)(=O)[C@H]1C</smiles>

$7 \mathbf{a}$

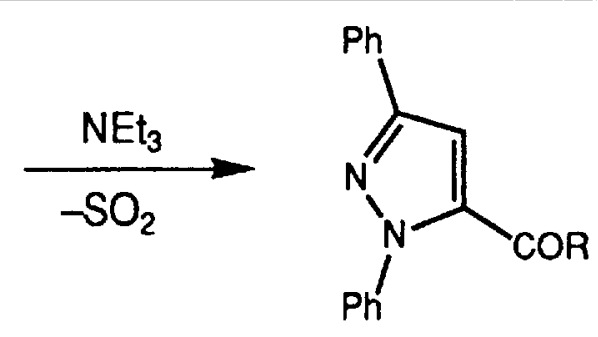

$8 \mathrm{R}=\mathrm{NHCH}_{2} \mathrm{CO}_{2} \mathrm{Et}$ $9 \mathrm{R}=\mathrm{OH}$ motives quite similar to the latter two cases, an amine function - in the case at hand an isocyanate group or one of its derivatives - can be liberated by exposing the isothiazoles first to a 1,3-dipole, then to heat. The process might be useful, particularly when isocyanate groups are to be generated from halides, while the sensitivity of the starting materials and/or the products dictate the observance of mild, neutral, and aprotic conditions.

The author would like to thank his colleagues of the Physics Department of $F$. Hoffntam-La Roche Ltd. for the IR spectra (Mr. A. Bubendorf), NMR spectra (Dr. W. Arnold), and MS (Dr. W. Vetter and Mr. W. Meister).

\section{Experimental Part}

(The author wishes to thank Mr. RolfDitmar and Mrs. Heidy Schär-Morath for their experimental work)

General. M.p.: uncorrected. IR spectra $\left(\mathrm{cm}^{-1}\right)$ : in $\mathrm{KBr}$. 'H-NMR spectra: chemical shifts in ppm rel. to TMS, coupling constants $J$ in $\mathrm{Hz}$. Correct elemental analyses were obtained for all compounds.

1. $[3+2]$ Addition of 2,3-Dihydro-2-henzyisothiazol-3-one I,I-Dioxide (1d) and I-(Azidomethyl)-4-methoxybenzene (3). A soln. of $1 \mathrm{~d}$ (223 $\mathrm{mg}, 1 \mathrm{mmol}$ ) and 3 [7] (245 $\mathrm{mg}, 220 \mu \mathrm{l}, 1.5$ $\mathrm{mmol})$ in dry toluene $(2.5 \mathrm{ml})$ was maintained at $100^{\circ}$ for $18 \mathrm{~h}$ with stirring. Upon slowly cooling, the initially clear soln., white crystals of anal. pure N-benzy/-I-(4-methoxybenzyl)-IH-I,2,3-miazole-4-carboxamide (6) (32 $\mathrm{mg}, 10 \%$ ) were deposited, and were collected by filtration. M.p. $201^{\circ}$. IR: $3310 s, 3080 \mathrm{~m}, 2840 w, 1655 s, 1618 w$, $1581 s, 1519 s$. 'H-NMR (80 MHz, CDCl $\left.{ }_{3}\right): 7.94$ $(s, 1 \mathrm{H}) ; 7.45(\mathrm{br} ., 1 \mathrm{H}) ; 7.31(m, 5 \mathrm{H}) ; A^{\prime} B B^{\prime}$

Scheme 3

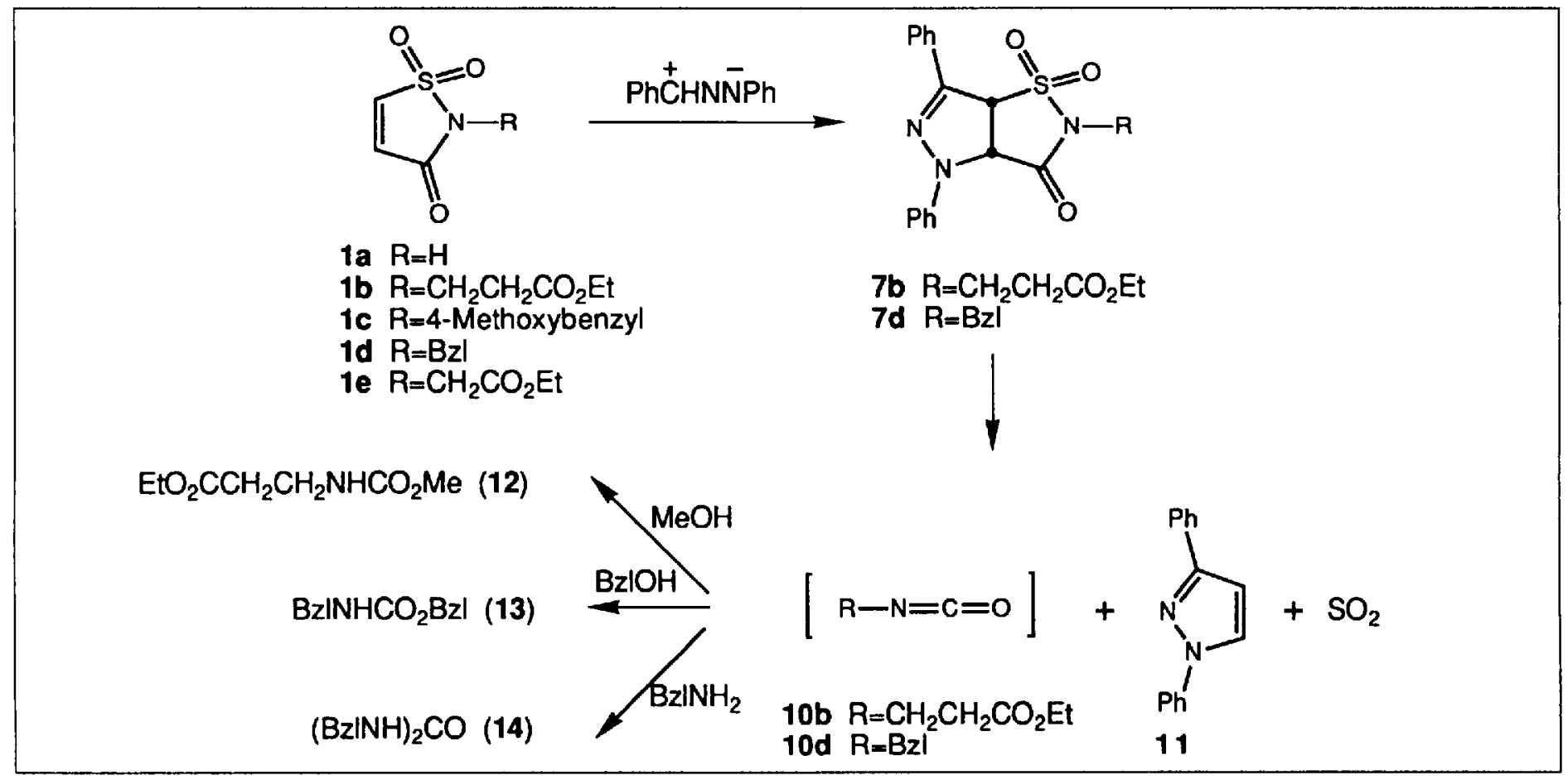




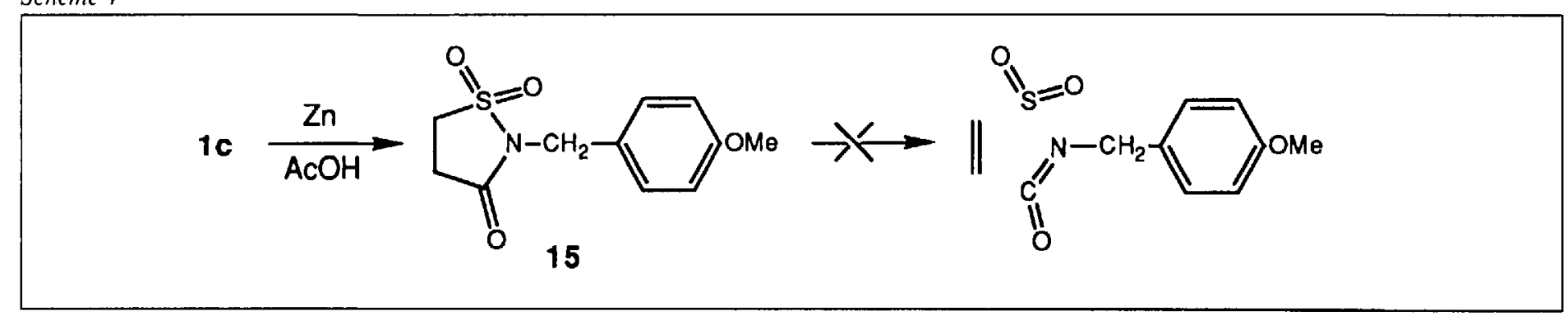

systems: $7.23(m, 2 \mathrm{H})$ and $6.90(m, 2 \mathrm{H}) ; 5.47(s$, $2 \mathrm{H}) ; 4.63(d, J=6,2 \mathrm{H}) ; 3.80(s, 3 \mathrm{H}) . \mathrm{MS}: 322$ $\left(M^{+}\right), 201 \quad\left(\left[M-\mathrm{CH}_{3} \mathrm{OC}_{6} \mathrm{H}_{4} \mathrm{CH}_{2}\right]^{+}\right), \quad 121$ $\left(\mathrm{CH}_{3} \mathrm{OC}_{6} \mathrm{H}_{4} \mathrm{CH}_{2}{ }^{+}\right)$. The filtrate, after evaporation, consisted mainly of 1-(4-methoxybenzyl) / H-l,2,3-triazole (5). Colorless crystals of anal. pure 5 (101 $\mathrm{mg}, 53 \%$ ) could be obtained by fractional crystallization from hexane/Et 2 O.M.p. 90-91. $5^{\circ}\left([6]: 89-91^{\circ}\right)$. IR: $3102 s, 2842 w, 1611 s$, $1581 \mathrm{~m}, 1516 \mathrm{~s}, 1484 \mathrm{~m} .{ }^{1} \mathrm{H}-\mathrm{NMR}(80 \mathrm{MHz}$ $\left.\mathrm{CDCl}_{3}\right): 7.75(d, J=1,1 \mathrm{H}) ; 7.53(d, J=1,1 \mathrm{H})$ $A A^{\prime} B B^{\prime}$ 'systems: $7.31(m, 2 \mathrm{H})$ and $6.97(m, 2 \mathrm{H})$ $5.54(s, 2 \mathrm{H}) ; 3.83(s, 3 \mathrm{H})$. MS: $189\left(M^{+}\right), 161$ $\left(\left[M-\mathrm{N}_{2}\right]^{+}\right), 121\left(\left[\mathrm{CH}_{3} \mathrm{OC}_{6} \mathrm{H}_{4} \mathrm{CH}_{2}\right]^{+}\right)$.

2. Base-Induced $\mathrm{SO}_{2}$ Elimination of the $\mathrm{Ni}$ trile Imine Adduct 7a; $\mathrm{N}-$ (1,3-Diphenylpyrazole5-carboxamido)glycine Ethyl Ester (8). A soln. of ethyl (cis-3,3a,4,6a-tetrahydro-4,6-diphenyl$2 \mathrm{H}$-pyrazolo[3,4-d] isothiazol-2-yl)acetate 1,1 dioxide (7a) [3] ( $1.00 \mathrm{~g}, 2.42 \mathrm{mmol})$ and $\mathrm{Et}_{3} \mathrm{~N}$ $(0.73 \mathrm{~g}, 1.01 \mathrm{ml}, 7.26 \mathrm{mmol})$ in $\mathrm{CH}_{2} \mathrm{Cl}_{2}(20 \mathrm{ml})$ was stored at ambient temp. for $14 \mathrm{~h}$. The solvent was removed under vacuum, and the residue was partitioned between $\mathrm{H}_{2} \mathrm{O}(100 \mathrm{ml})$ and $\mathrm{AcOEt}$ (twice $70 \mathrm{ml}$ ). The org. phases were washed with $\mathrm{NaCl}$ soln., combined, dried $\left(\mathrm{Na}_{2} \mathrm{SO}_{4}\right)$, and evaporated, leaving $840 \mathrm{mg}$ of a yellowish solid. After recrystallizing from $\mathrm{CH}_{2} \mathrm{Cl}_{2}$ /hexane, yellowish crystals of anal. pure $8(640 \mathrm{mg}, 76 \%)$ were collected. M.p. 151-152 ${ }^{\circ}$. IR: 3300 s, 3120w, $1754 s, 1653 s$. 'H-NMR (90 MHz, (D 6 )DMSO): $9.21(d, J=7,1 \mathrm{H}) ; 7.87(m, 2 \mathrm{H}) ; 7.44(m, 9 \mathrm{H})$; $4.05(q, 2 \mathrm{H}) ; 3.97(d, J=7,2 \mathrm{H}) ; 1.21(t, 3 \mathrm{H}) . \mathrm{MS}$ $349\left(M^{+}\right), 247\left(\left[M-\mathrm{NHCH}_{2} \mathrm{CO}_{2} \mathrm{Et}\right]^{+}\right), 219([247-$ $\mathrm{CO}]^{+}$). For further identification, 8 was hydrolyzed to /,3-diphenylpyrazole-5-carboxylic acid (9) [8] by refluxing in $6 \mathrm{~N} \mathrm{HCl}$ for 14 h. M.p. $228^{\circ}$.

3. 2,3-Dihydroisothiazol-3-one 1,I-Dioxide (1a) was prepared according to the literature method [ 10 ] from the corresponding $N$-tert-butyl compound.

2,3-Dihydro-2-(4-methoxybenzyl)isothiazol3-one 1,1-Dioxide (1c) was synthesized as described previously [3].

Ethyl (2,3-Dihydro-3-oxo-isothiazol-2yl)propionate 1,1-Dioxide (1b). To a soln. of 1a $(2.0 \mathrm{~g}, 15.0 \mathrm{mmol})$ in dry DMF $(30 \mathrm{ml}$; from $4 \AA$ sieves) was added $\mathrm{NaH}(0.72 \mathrm{~g}$ of a $55 \%$ dispersion in oil, $30.0 \mathrm{mmol}$ ), and the suspension was stirred at r.t. for $1 \mathrm{~h}$. Under Ar, freshly distilled ethyl 3-bromopropionate $(8.1 \mathrm{~g}, 5.7 \mathrm{ml}, 45 \mathrm{mmol})$ was added, and the mixture was stirred for $5 \mathrm{~h}$ at $80^{\circ}$. It was poured into ice-cold $\mathrm{H}_{2} \mathrm{O}(300 \mathrm{ml})$, and neutralized with $1 \mathrm{~N}$ aq. $\mathrm{HCl}$. The aq. phase was extracted with $\mathrm{CH}_{2} \mathrm{Cl}_{2}(4 \times 100 \mathrm{ml})$, the org. phase was dried $\left(\mathrm{Na}_{2} \mathrm{SO}_{4}\right)$, and the volatile components were removed under high vacuum. The remaining yellow oil was chromatographed on silica gel ( $\left.100 \mathrm{~g} ; \mathrm{CH}_{2} \mathrm{Cl}_{2} / \mathrm{MeOH} 49: 1\right)$, affording a yellowish liquid of anal. pure $1 \mathrm{~b}(1.95 \mathrm{~g}, 55 \%)$. ' $\mathrm{H}-\mathrm{NMR}\left(60 \mathrm{MHz}, \mathrm{CDCl}_{3}\right): 7.50,6.83(A B, J=$
$7.5) ; 4.13(d d, 2 \mathrm{H}) ; 3.95(t, 2 \mathrm{H}) ; 2.77(t, 2 \mathrm{H})$; $1.23(t, 3 \mathrm{H})$

2-Benzyl-2,3-dihydroisothiazol-3-one 1,1-Dioxide (1d) was prepared in $87 \%$ yield from 2 benzyl-2,3-dihydroisothiazol-3-one [11] by $\mathrm{m}$ chloroperbenzoic acid oxidation [5]: white crystals from $\mathrm{CH}_{2} \mathrm{Cl}_{2}$ /hexane. M.p. 90-91 $1^{\circ}$. MS: 223 $\left(M^{+}\right), 159\left(\left[M-\mathrm{SO}_{2}\right]^{+}\right)$

4. 1,3-Dipolar Adducts of 1 with Diphenyl Nitrile Imine. The adducts were prepared as described previously [3]: 7a: pale yellow crystals from $\mathrm{CH}_{2} \mathrm{Cl}_{2}$ /hexane in $50 \%$ yield from 1e [5]. M.p. 132-132.5'; ethyl (cis-3,3a,4,6a-tetrahydro-4,6-diphenyl-2H-pyrazolo [3,4-d]isothiazol2-yl)propionate 1,1-dioxide (7b):yellow crystals from $\mathrm{CH}_{2} \mathrm{Cl}_{2} /$ hexane in $68 \%$ yield from 1 b. M.p. 128-129 . IR: $1738 s, 1600 s, 1560 w, 1500 s$. MS: $363 \quad\left(\left[M-\mathrm{SO}_{2}\right]^{+}\right), \quad 220 \quad\left(\left[M-\mathrm{SO}_{2}-\right.\right.$ $\left.\left.\mathrm{OCNCH}_{2} \mathrm{CH}_{2} \mathrm{CO}_{2} \mathrm{Et}\right]^{+}\right)$; and 2-benzyl-4,6a-dihy dro-4,6-diphenyl-2H-pyrazolo [3,4-d]isothiazol$3(3 a \mathrm{H})$-one 1,1 -dioxide $(7 \mathrm{~d})$ : yellowish crystals from $\mathrm{CHCl}_{3}$ in $65 \%$ yield from 1d. M.p. 152 $153^{\circ}$. IR: $1741 s, 1602 s, 1501 s$. MS: 353 ([M$\left.\left.\mathrm{SO}_{2}\right]^{+}\right), 220\left(\left[\mathrm{M}-\mathrm{SO}_{2}-\mathrm{BzINCO}\right]^{+}\right), 133(\mathrm{BzIN}-$ $\mathrm{CO}^{+}$.

5. Thermally Induced Fragmentation of the Diphenyl Nitrile Imine Adducts 7 . A soln. of $7 \mathbf{d}$ (417 mg, $1.0 \mathrm{mmol})$ and $\mathrm{PhCH}_{2} \mathrm{OH}(162 \mathrm{mg}, 155$ $\mu \mathrm{l}, 1.5 \mathrm{mmol})$ in dry toluene $(2.5 \mathrm{ml})$ was stirred at reflux temp. for $1.5 \mathrm{~h}$ under $\mathrm{Ar}$. The solvent was evaporated, and the remaining brown oil was chromatographed on silica gel $(20 \mathrm{~g}$, benzene). The first fraction, a white solid, consisted of I.3diphenylpyrazole (11) (220 mg, 100\%). Recrystallization from pentane gave $132 \mathrm{mg}$ of white crystals. M.p. $84-85^{\circ}$ ([9]: 86-87'), MS: 220 $\left(M^{+}\right)$. The second fraction, a colorless oil, proved to be benzyl N-benzylcarbamate $(13)(170 \mathrm{mg}$, $70 \%$ ). Recrystallization from $\mathrm{Et}_{2} \mathrm{O} /$ pentane gave $92 \mathrm{mg}$ of white crystals. M.p. $64^{\circ}$ (reported: $64^{\circ}$ [12]). In full analogy, thermolysis of $1 \mathrm{mmol}$ of $7 \mathrm{~b}$ and $4 \mathrm{mmol}$ of $\mathrm{MeOH}$ in dry toluene $(2.5 \mathrm{ml}$ ) after $5 \mathrm{~h}$ under $\mathrm{Ar}$ at reflux temp., afforded after chromatography on silica gel $\left(50 \mathrm{~g}, \mathrm{CH}_{2} \mathrm{Cl}_{2}\right.$, followed by $\left.\mathrm{CH}_{2} \mathrm{Cl}_{2} / \mathrm{EtOAc} 1: 1\right)$ white crystals of $11(190 \mathrm{mg}, 86 \%)$. M.p. $82-84^{\circ}$, and $\mathrm{N}$ (methoxycarbonyl)-B-alanine ethyl ester (12) as a colorless oil $(130 \mathrm{mg}, 74 \%) .{ }^{1} \mathrm{H}-\mathrm{NMR}(60 \mathrm{MHz}$, $\mathrm{CDCl}_{3}$ ): 5.6-5.1 (br., $\left.1 \mathrm{H}\right) ; 4.13(\mathrm{dd}, 2 \mathrm{H}) ; 3.66(s$, $3 \mathrm{H}) ; 3.44(d d, 2 \mathrm{H}) ; 2.51(t, 2 \mathrm{H}) ; 1.24(t, 3 \mathrm{H})$. Furthermore, thermolysis of $1 \mathrm{mmol}$ of $7 \mathbf{d}$ was carried out in dry toluene $(2.5 \mathrm{ml})$ in the absence of any alcohol. After $1 \mathrm{~h}$ at reflux temp., the soln. was allowed to cool to $20^{\circ}$, and benzylamine (107 $\mathrm{mg}, 109 \mu \mathrm{l}, 1 \mathrm{mmol}$ ) was injected, whereby the precipitation of white product was started. After $30 \mathrm{~min}$, the solid was collected by filtration and dried. White crystals of anal. pure I,3-dibenzylurea (14) (200 mg, 83\%). M.p. I68-169 ([13]: $171^{\circ}$ ). The filtrate, on evaporation, consisted of spectroscopically ('H-NMR) pure 11 (white solid, as above).
6. 2,3-Dihydro-2-(4-methoxybenzyl)isothiazol-3-one 1,1-Dioxide (15). A soln. of $1 \mathrm{c}(3.0 \mathrm{~g}$, $11.8 \mathrm{mmol})$ in glacial $\mathrm{AcOH}(72 \mathrm{ml})$ and $\mathrm{H}_{2} \mathrm{O}(8$ $\mathrm{ml}$ ) was cooled with an ice-bath, and $\mathrm{Zn}$ dust ( 6 g) was added in one portion. After vigorously stirring for 15 min at $0-5^{\circ}, \mathrm{Zn}$ was removed by filtration, and the filtrate was poured into $5 \%$ aq. NaOAc soln. (1.6 I). The product was extracted with three $200 \mathrm{ml}$ portions of $\mathrm{CH}_{2} \mathrm{Cl}_{2}$, the combined org. phases were dried $\left(\mathrm{Na}_{2} \mathrm{SO}_{4}\right)$ and evaporated. The white residue $(2.91 \mathrm{~g}, 96 \%)$, after onc recrystallization from $\mathrm{CH}_{2} \mathrm{Cl}_{2}$ /hexane, afforded white crystals of anal. pure $15(2.51 \mathrm{~g}, 83 \%)$. M.p. 125-126'. IR: $2842 \mathrm{~m}, 1722 \mathrm{~s}$. 'H-NMR (60 MHz, $\left.\mathrm{CDCl}_{3}\right): A A^{\prime} B B^{\prime}$ systems: $7.35(\mathrm{~m}, 2 \mathrm{H})$ and 6.83 $(m, 2 \mathrm{H}) ; 4.64(s, 2 \mathrm{H}) ; 3.79(s, 3 \mathrm{H}) ; A^{\prime} B B^{\prime}$ systems: $3.55(m, 2 \mathrm{H})$ and $3.04(m, 2 \mathrm{H})$. MS: 255 $\left(M^{+}\right), 191\left(\left[M-\mathrm{SO}_{2}\right]^{+}\right)$.

7. Attempted Fragmentation of 15. A soln. of 15 ( $128 \mathrm{mg}, 0.5 \mathrm{mmol}$ ) and (optionally) $\mathrm{PhCH}_{2} \mathrm{OH}$ $(81 \mathrm{mg}, 78 \mu, 0.75 \mathrm{mmol})$ in dry toluene $(1.5 \mathrm{ml})$ was heated to reflux temp. for several days. TLC and 'H-NMR monitoring reveals the presence of starting components only, with no indication of decomposition

Received: July 8, 1992

[1] U.S. Patent 4,180,662; Eur. Pat. 1113, both to $F$. Hoffmann-La Roche Lid.

[2] D. Binder, O. Hromatka, F. Geissler, K. Schmicd, Ch. R. Noc, K. Burri, R. Pfister, K. Strub, P.Zeller, J.Med.Chem. 1987,30, 678.

[3] K. F. Burri, Helv. Chim. Acta 1989, 72, 1416.

[4] K. F. Burri, Helv. Chim. Acta 1990, 73, 69.

[5] S. N. Lewis, G. A. Miller, M. Hausmann, E. C. Szamborski,J.Heterocycl. Chem.1971, 8,591 .

[6] R. A. Wildonger, U.S. 4,227,004; 07 Oct 1980 to $\mathrm{ICl}$ Americas, Inc'., CA 94, $\mathrm{P}$ 84138 c. N. Bruvele, E. Gudriniece, Lat?. PSR Zinat. Akad. Vestis, Kim. Ser. 1970, 198 (CA: 73, 56037s).

[7] F. Moulin, Helv. Chim. Acta 1952,35, 167.

[8] R. Huisgen, M. Seidel, G. Wallbillich, $H$. Knupfer, Tetrahedron 1962, 17, 3.

[9] H. L. Davies, J. Am. Chem. Soc. 1941, 63, 1677

[10] M. Abou-Gharbia, J. A. Moyer, U. Patel, M. Webb, G. Schiehser, T. Andree, J. T. Haskins, J. Med. Chem. 1989, 32, 1024.

[11] S.N. Lewis, G. A. Miller, M. Hausmann, E. C. Szamborski,J.Heterocycl.Chem. 1971, 8,571 .

[12] D. Ben-Ishai, A. Berger, J. Org. Chem. 1952, 17, 1564

[13] J. Chapman, F. J. Wilson, J. Chem Soc. 1931, 507. 